\title{
研究余滴
}

滋賀大学名誉教授, 学校法人聖泉学園顧問

井深 信男

\section{Jottings about my research life}

\author{
Nobuo IBUKA \\ Honorary Professor of Shiga University, Advisor of Seisen University \\ 6-1085-39 Nango, Ohtsu, Shiga 520-0865, Japan
}

長い期間, 大学と研究所に身をおき, 教育と研究に 携わってきた。ある先達に 70 歳を超えたら, “人生” という言葉は，他人が聞いても，気障に響かないよう になる, と言われた。その歳になり, 未だ人生を語る 心境ではないが, 日本生理心理学会創立 30 周年の節 目に, 若い皆さんの何かに役立てばとの思いで, これ までの大学・研究所での活動の軌跡を記している。

\section{1. 大学院のころ}

東京教育大学 (現筑波大学) での学部時代は, それ でも大学は機能していたが, 大学院に入学したころか ら, 全国的に, 大学紛争が始まり, 博士課程に進学し たころには, 大学にはバリケードが築かれ, 動物実験 室も完全に封鎖され, 授業や研究どころでなくなつた。 余り政治的にも熱くなれなかった私は, 設立間もない 京都大学霊長類研究所の共同利用研究員となり, それ までラットで調べていた探索行動を, より高次のサル の視覚的探索行動に転じ, 薬物により覚醒レベルを操 作し, 覚醒水準と探索活動発現の関係を調べた。もと
もと, 探索行動は, 脳の覚醒水準を維持するために, 外的刺激を取り入れる行動が表出されたものと考えて いたので, 覚醒剤投与されたサルは, 探索行動が減少 するだろうとの仮説の検討であった（Primates, 1970, 1971; Jap.Psychol.Res., 1971; 心研, 1972)。

アカゲザルを使ったが, 私の感じでは, 体重が $3 \mathrm{~kg}$ を超えると, もはやサルは野獣であり, 噛まれると大 変である。当時, アカゲザルを使うときは, 夕モを渡 され, 集団飼育ケージから好きな個体を選んで良いと 言われたが，その動きは敏捷で，捕獲に手間取り実 験を開始するまでに，息切れするほどであった。霊長 研は設立間もなく, 大変活気に溢れ, 心理部門に室伏 靖子先生, 助手に浅野俊夫さん, 渡辺允子さんがおら れた。また, 神経生理部門に助手として二木宏明先生 がおられ，昼夜を問わず，猛烈に実験していた。霊長 研で心理学と生理学のカルチャーの違いを感じさせら れ, 大変勉強になった。ご承知のように, 多くの心理 学の研究者がこの共同利用研究員制度を利用し, 成果 をあげられている。サルのような大型動物は, 個別の 研究機関で飼育, 研究するよりは, 霊長類研究所のよ

2012.7.25 受稿，2012.7.25 受理，2012.12.28 J-STAGE 早期公開， doi: 10.5674/jjppp.1207si，JOI: JST.JSTAGE/jjppp/1207si

連絡者及び連絡先：干 520-0865 滋賀県大津市南郷 $6 丁$ 丁 1 1085-39 井深信男

E-mail: ibuka-n@seisen.ac.jp 
うに集中的に投資した方が，効率的であり，その後 の共同利用研究所のモデルとなったのではないだろう か。

\section{2. 三菱化成生命科学研究所の時代}

就職の目処がなく, 博士課程在籍期限の 6 年目に, 縁あって新設された三菱化成生命科学研究所の川村浩 先生の脳神経生理学研究室に採用された。採用の方法 がユニークで, 今までにやってきた研究を 30 分, 研 究所に入ったらやりたいことを 30 分，述べよという ものであった。川村先生と所長の江上不二夫先生が質 疑を交え，私の思いを黙って聞いてくれた。1 時間ほ ぞ待機させられ，川村先生より採用を告げられた。そ の時，言われたことは，自分の権限と責任で採用する ので，期待に応えてくれとのことであった。今にして 思うと，アメリカのポスドク採用のやり方であった。

川村先生は, 東大脳研の時実利彦先生のご一門で, 非常に早くから “行動”に関心を示されていた数少な い脳生理学者のお一人であった。外国での研究生活が 長く, 岩波からパブロフの“条件反射”を翻訳されて いた。このラボで初めて, 肉体を酷使することにより データを生み出す文化に馴染んだ。

先生のご指導のもと, 最初に取り組んだテーマが, メラトニンを産出する松果体と睡眠の関係であった。 手術を含め, 脳波を記録するのに, 大型動物が適して いたので，ネコを使つた。半野生の猫に麻酔する時が 苦労で, 常に引つ掻き傷, 覚悟であった。ところが, 麻のドンゴロスの袋をネコの頭からすっぽりとかぶせ ると，目隠し状態となるため，おとなしくなり，腹部 にうまく注射することが出来た。

ネコの脳は個体差が少なく, 大きいため, 脳波の慢 性電極の装着など実験動物として優れていたが, 睡眠 の昼夜のリズムが極めて，不明瞭であり，松果体を摘 出しても,いまひとつその効果がはっきりしなかった。

あるとき, 川村先生より視交叉上核 (suprachiasmatic nucleus, $\mathrm{SCN}$; 図 1）を狙ってみるよう，指導を受けた。 その存在は, 解剖学の教科書には記載されていたもの の, 機能は全く不明であった。もともと生物リズムに 強い関心を持っていたので, この時点で, 動物を概日 リズムの明瞭なラットに切り替えた。記録紙を 1 分間 に $3 \mathrm{~cm}$ と極めて遅い速度で流しても, 脳波と筋電図,
それに眼球運動を記録すれば，ノンレム睡眠，レム睡 眠，覚醒の 3 相に明瞭に判別できた。ヒトと異なり， 動物は常に動き回るので，記録コードがすぐよじれ， 睡眠脳波の長時間記録は不可能であった。当時の日本 には，これを解消する技術が未だなく，フランスより スリップ・リングを取り寄せた。また，脳定位固定装 置とコネクターも外国製であった。問題は, 視床下部 にある極小 $(0.3 \times 0.4 \times 0.7 \mathrm{~mm})$ の視交叉上核 $(\mathrm{SCN})$ のみを選択的に通電破壊することであった。うまく SCN が両側破壊されると, 昼間に多発するラットの 睡眠は，完全に消失し，昼夜の差が見られなくなった (Brain Res, 1975, 1977)。この研究報告には多くの文献 請求を頂いたが，SCN 破壊により，活動性や摂食行 動といった単なる表現型でなく，脳活動そのものを反 映する脳機能の概日変動が消失することを見出したこ とによるものだと思っている。しかも, 面白いことに, 一日に出現する睡眠総量は, 術前と術後で変化がな かった。このことは, 脳は正常に機能しているが, 脳 の計時機能のみが選択的に損なわれることを示唆して いて, 極めて重要である。これらの研究は, 海老原（時 間生物学，2010）によれば，我が国の概日時計の生理 学的研究の先陣となり, その後に続く視交叉上核研究 の発展の基礎となった，と位置づけられている。

その後, SCNが概日リズムを生みだす生物時計で あることを証明するために，川村研究室より相次いで 注目すべき論文が発表されたが，間違いなく，これ らの研究は, その後の概日リズムの神経科学的研究 を世界的規模で牽引した。中でも，ラットの $\mathrm{SCN} へ$

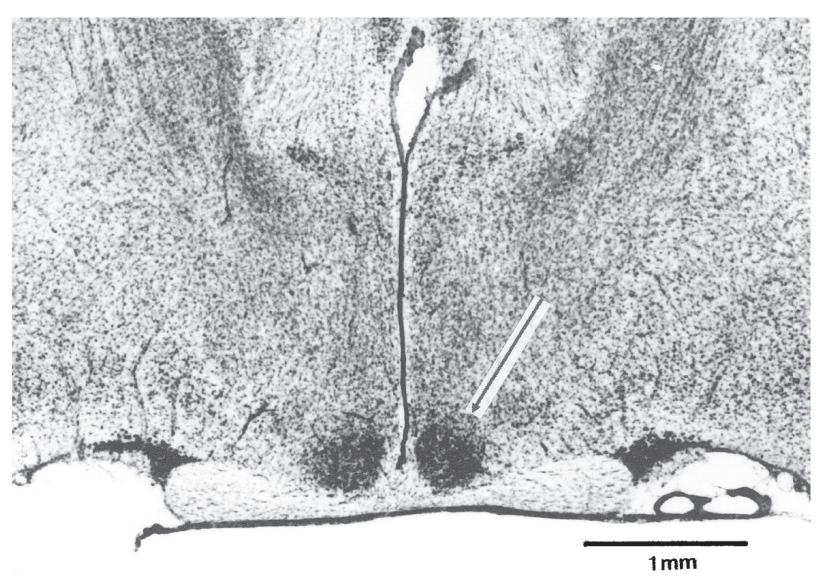

図 1. ラットの視交叉上核 (矢印), 視神経の真上に位 置している。 
の入出力を外科的に遮断した “島標本”で島内部から のみ，複数ニューロン（MUA）の概日変動が検出さ れたことは，SCNが概日時計本体であることを強く 示し，注目を浴びた（Inouye, \& Kawamura, 1979)。更 に, 予め SCN を損傷したラットに, 新生仔の SCN を移植すると，概日リズムが復活することも，一層， SCN が概日時計であることを強く印象づけた (Sawaki, Nihonmatsu, \& Kawamura, 1984)。

実は，初めてこの視交叉上核が概日時計としての可 能性を脳損傷により, Proc.N.A.S. と Brain Res. 誌に発 表した二つのグループが Zucker, I. と Moore, Y. R. た ちで，1972 年のことであった。今日，概日時計とし ての視交叉上核を語るとき, 彼らの先見性にはただ脱 帽するばかりである。Zucker 教授はカナダのマッギ ル大学で Hebb の心理学の講義を聴き, 数学から心理 学に転向した，とのことであった。かれらの業績は, 概日時計の生理学的研究では必ず引用される画期的業 績で，同学の心理学を学んだものとして大変うれし く思っている。Zucker 教授のもとからは，Dr. Stephan やDr. Rusak, Dr. Smale, 他何人かの優れたリズム研 究者が巣立つている。日本で最も早い時期 (1978) に, 東京の経団連会館で開催された生体（物）リズムに関 する国際シンポジウムに招待された折に, 彼とお会い する機会があった。後に, 文部省在外研究員として彼 のラボで研究させてもらうこととなったが，現在は， UC Berkeley の名誉教授である。

これらの神経科学的な手法により, SCN が生物時 計であることが証明されると共に, 多くの研究者が視 交叉上核研究に参入し, 後に, 程肇による哺乳類にお ける時計遺伝子の発見, 岡村均の概日時計の分子機構 の解明，近藤孝男によるシアノバクテリア時計機構の 研究など, 我が国の時間生物学は国際的にも誇るべき 成果をあげている。また, 2003 年, 北大の本間研一 教授が第 1 回時間生物学世界大会を札幌で開催するな ぞ, 日本における時間生物学研究の水準は, 国際的に も極めては高く評価されている。心理学からも Rusak 教授のもとへ留学し, 本間研究室で学ばれた福井医大 の安倍博教授, 他の皆さんが活躍されている。ただ, 最近では時間生物学の研究方向が, 益々, ミクロな方 向へ傾斜し, 行動レベルでの研究が少なくなっており, 心理学からの参入が難しくなっているのがさびしい限 りである。三菱生命研の生活は，絶えず世界を意識し
ながら,ただただ研究にひたむきに専念できた楽しく, 充実していた時代であった。

\section{3. 滋賀大学での研究と教育}

これもまた縁としか言いようがないが，1976 年秋 に滋賀大学教育学部に転出した。月給は $2 / 3$ となり, 研究環境は三菱時代とは比ぶるべくもなかった。ただ, 滋賀大学は地方大学としては珍しく，関口茂久教授が マウスの行動遺伝学で成果をあげられ，心理学での動 物実験の伝統があった。私には, 生理心理学のラボを 立ち上げることが期待された。心理学で動物実験を続 けようと思うと, 当然, 動物の維持・管理の施設と人 出が必要となり, 昔も今も, 限られた環境しかないの が，きわめて残念である。

幸運にも，数年後に研究棟の改築があり，これに合 わせ動物で生理学的な実験ができるラボを立ち上げる ことが出来た（図 2）。基本的には，三菱生命研以来

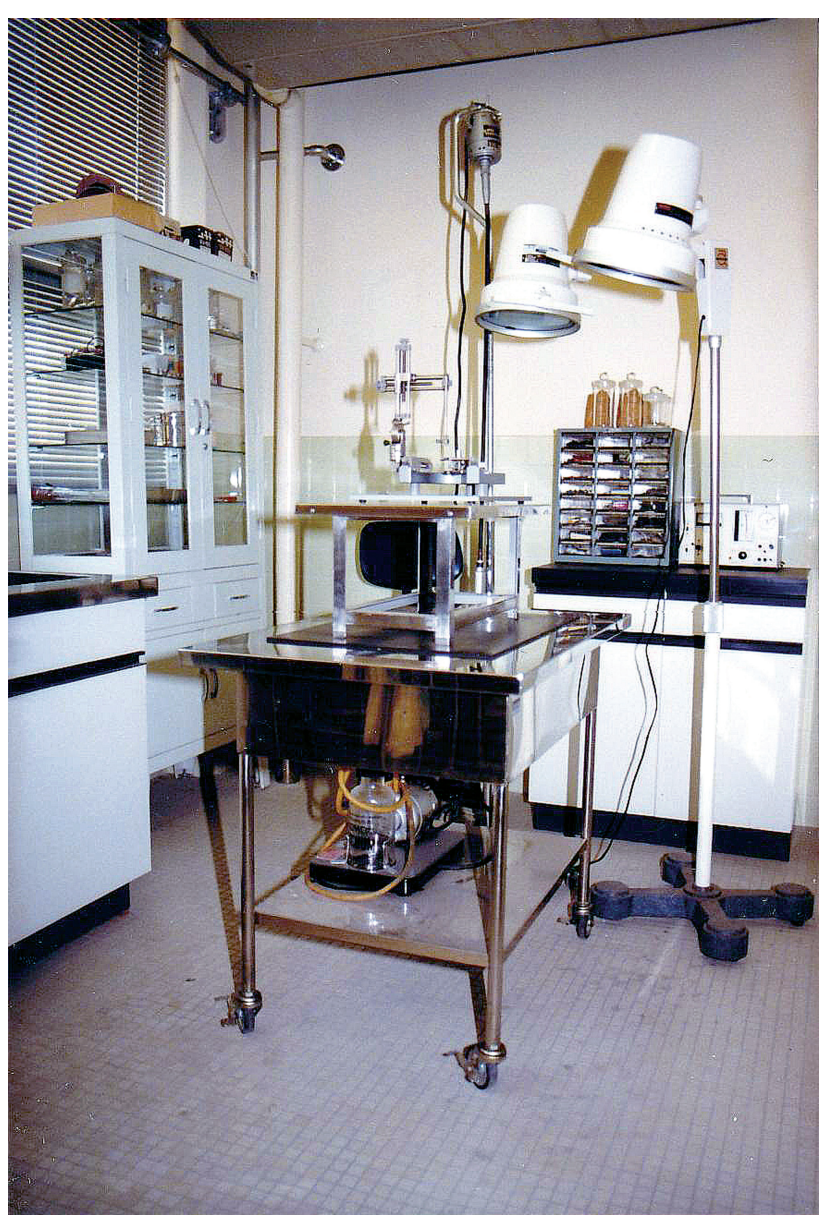

図 2. 動物用の脳生理学実験手術室 
のテーマである睡眠の概日リズムを軸に，マウスでの 視交叉上核の破壊（Waking Sleeping, 1980)，睡眠リズ ムの発達特性を早熟性のモルモットと晚塾性のラット で比較（Behav.Brain.Res., 1984）, 遺伝的に両眼球を 欠損したラットの視交叉上核特性と睡眠リズムの関係 (Physiol.Behav., 1987) 等, を主に調べた。いろいろ印 象に残っているが, モルモットは形態, 運動, だけが 早熟でなく, 生後 1 日ですでに脳波が記録可能で, そ のパタンも成体に匹敵した。先天性両眼球欠損ラット の視交叉上核は, 健常ラットに比べ小さいものの, 概 日リズムを生みだすには十分であった。また，この実 験では, 実験動物中央研究所からオス 1 匹, メス 1 匹 を分与してもらい, これを繁殖させ実験に供したが, 実験用の動物を確保するのに長期間を要したことが, 強く印象づけられた。

赴任した時は, 助教授で, 講義・演習の他は, 大き な校務もなく, 研究と学生指導に集中できた。何せ, 24 時間一日中脳波計を動かしているので, いつも気 が抜けず，これが最大の悩夕であつたが，道路一つ隔 てた官舎に住んでいたことで, 救われた。落雷・停電 の時は, 夜中であっても守衛より, 直ちに私に通報さ れた。

このころは, 私も若く, 自ら先頭に立ち, 実験し, デー 夕を出した。学部学生も, 今から思うと, 大分難しい 英文ジャーナルを読ませたが, よくついてきてくれた。 睡眠の概日リズム研究において, 最大の問題はデータ 処理であった。データ入力は紙テープの時代で, 1 日 の記録のデータ処理に, 数時間を要した。このスタイ ルの研究と教育が在外研究まで続いた。

在外研究には強い思いがあり, 滋賀大学赴任の翌年 から, 希望を出していた。その場合の留学先は, 先述 の Zucker 教授の研究室と決めていた。最大の理由は, 彼の研究室のテーマが私の関心領域と重なっていたこ とである。彼の研究室には人工気象室が備えられ，い つでも哺乳類で季節リズムが研究できる環境が整つて いた。元来, 時間生物学の分野でも, 季節リズム研究 は少なく, 当時の日本では, 昆虫類での研究が主であつ た。その理由の一つは, 研究に長期間を要し, 実験室 のスペースをはじめとする環境条件の確保が, 哺乳類 では困難であったためと思う。アメリカのような競争 主義の国では, 短期間で成果の上がる研究ばかりのよ うに, よく言われるが, そのようなことはなく, 理念
と研究目的がしつかりとしていれば，長期間を要する 研究も, 手厚い支援がなされている。そのことは彼の ラボの潤沢なグラントが物語っていた。

1985 年 10 月から, 彼のラボで仕事した。実験室と 図書館の往復, それがすべてに優先した。実験に携わつ ていると, 時々, 感動する場面に遭遇するが, キンイ ロジリスの冬眠からの目覚めには, 全く, 驚かされた。 冬眠中の動物を実験室から取り出し, 常温の部屋に置 くと, 数時間して目覚める。冬眠中, その動物は毢の ように丸くなり, 鼻先はほのかにピンクで, 時々, 髭 を動かすが, 前肢に触れると大変冷たい。前肢に触れ た時の感触と, 目覚めの過程で見せるスローモーショ ンは全くもって感動的であった。この時の体験が, 帰 国後, 冬眠研究を始める大きな動機となつた。

\section{冬眠のことなど}

よく誤解されるが, 動物は冬眠に入ると, 一冬の間, 目覚めることなくずっと低体温を維持し, 深い眠り状 態にあると理解されているが, そのようなことは決し てない。全ての冬眠哺乳類は, 必ず, 途中覚醒する。 その周期は種により, 数日から十数日にわたる。 2 日 以上持続する低体温状態を冬眠といい，1 日で終了す る低体温状態を daily torpor（日内休眠）と区別してい る。

動物を秋・冬を模した明 8 時間：暗 16 時間の短日, 低温環境に置くと, 1 から 2 ケ月で, シベリアハムス ターは日内休眠を見せる (図 3)。彼らとの共同研究で, 視交叉上核の破壊により, この日内休眠の季節リズム が，完全に消失することを見出し，松果体と並び，視 交叉上核が季節時計としてきわめて，重要なことが分

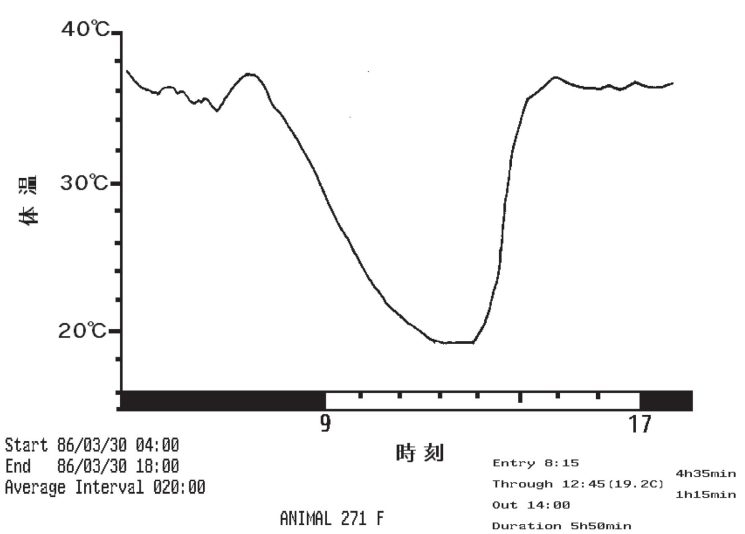

図 3. シベリアハムスターの日内休眠。短日寒冷環境 で，体温を $20^{\circ} \mathrm{C}$ 程度まで降下させる。 
かった（Am.J.Physiol, 1989)。シベリアハムスターは 短日寒冷の環境に曝されると, 精巣委縮と並行して, 体毛を真っ白に変化させ, それはとても美しく, 見事 なものであった。それを彼らは，ウィンター・コート を着るとエレガントに表現する。

帰国後, 日長を完全にコントロールできるコフィン （棺桶様遮光ボックス）を導入し, 実験室を一新し, 季節リズム研究体制に模様替えした。動物も, 野生を 残すハムスターに換えた。彼らは, ラット・マウスと 異なり，短日に応答して，精巣を委縮する性質を今な お維持し, 明瞭な光周性を示す。季節リズムとして, 冬眠（図 4）と生殖行動（精巣機能）を取り上げた。 当時の日本では, 全くと言つてよいほど, 哺乳類では 季節リズム研究に手がつけられていない状態であっ た。

学生指導に当たり, 極力, 心理学的視点の導入を心 がけた。3 回生から, 学生と一緒に実験し, いくつか の面白い（自分ではそのように思っている）成果を得

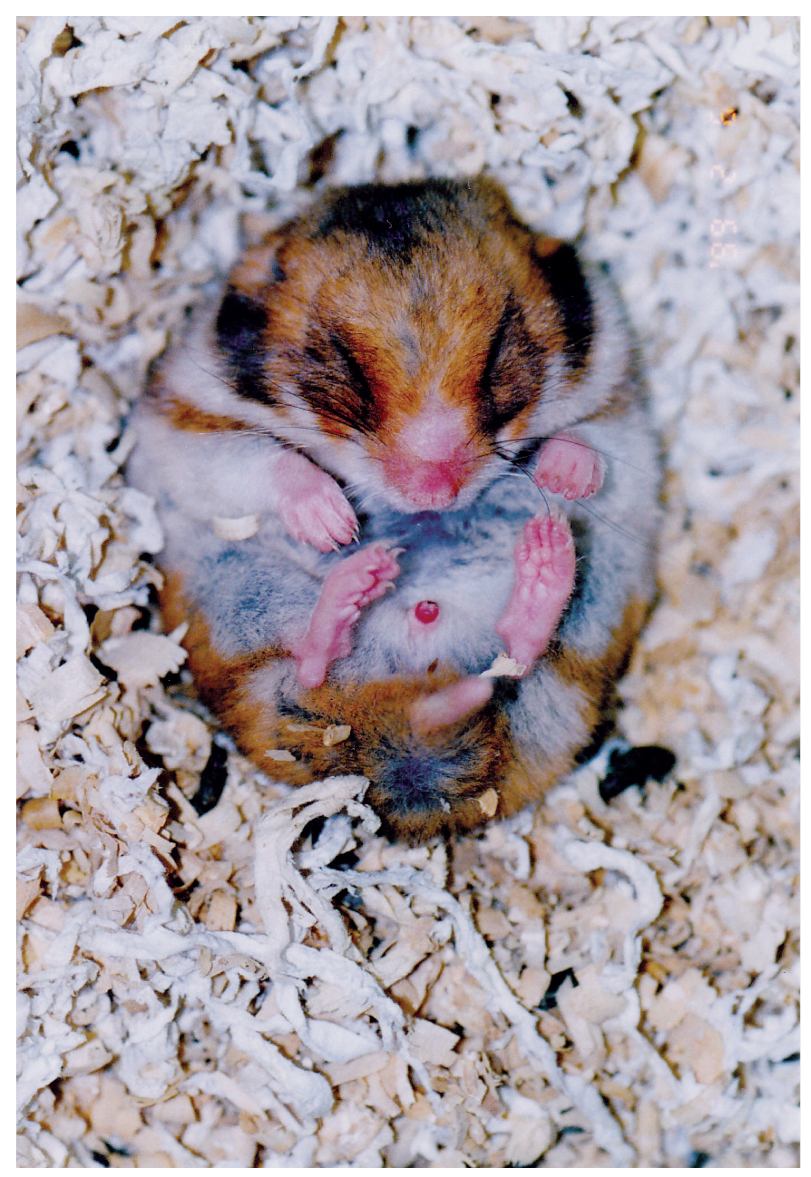

図 4. 冬眠中のシリアンハムスター。乎のように特有 の姿勢をとる。
た。

冬眠は寒冷・短日環境で誘発されるが，むしろ，直 接的には，餌の欠乏によるストレスが，冬眠惹起の引 き金として働く。確かに，餉の欠乏は自然界での最大 のストレスであるが，動物が剥奪日を予測できるよう な事態は, 動物にとって大きなストレスとはならない。 同じ確率で慨を剥奪しても，剥奪日を予測出来できな い条件下で，動物は長く冬眠する。例えば，全実験期 間の $25 \%$ の日に餌を剥奪しても，4 日ごとに 1 日の場 合と予測不能のランダムな系列日では, 後者の条件で, 動物はより長く, より多く冬眠する（Physiol.Behav., 1995, 1997)。この予測不能のストレスは，単に，冬眠 だけでなく，体重と精巣発達を大きく抑制することも 明らかとなった（Physiol.Behav., 1993）。餌の入手を予 測できる場合には，動物は，たとえ慨が入手できなく ても, 緊張とストレスを感じることはなく, 次にいつ, 餌にありつけるかわからない時に，長く冬眠し，厳し い冬をやり過ごすのだろう。

さらに, 冬眠の発生は, 動物の発達段階により異な り, 幼体, 若年, 老齢動物を比べると, 加齢につれ, 動物は早く冬眠に入り，長く冬眠することも分かった (Chronobio.Int., 2000)。その理由として, シリアンハ ムスターでは幼体を, 短日環境に暴露しても, 精巣発 達を抑制する効果が微弱なため, 冬眠が誘発されない と考えられる。

俗に，“血がさわぐ，血が熱い”と良く言われる。 精巣が大きく, 雄性ホルモンを生産している限り, 冬 眠は生起しない。冬眠には, どうしても, 精巣が完全 委縮しテストステロンの働きが, 停止する必要がある。 それが証拠に, 精巣を摘出すると, 冬眠生起は早まる。 光周性のことなど

シリアンハムスターの光周性を調べ始めのころ, 妙 なことに気付いた。それは外国の文献で発表されてい る体重・精巣重量より, 私たちの実験室のハムスター の方が, 常に, 重いことであった。ある会社のラット・ 八ムスター用固形飼料を使つていたが，草食動物用固 形飼料に切り替えると, スタンダードな值が得られた。 多分, 彼らは, 自然ではいつも栄養豊かな餌にありつ くわけでないのであろう。

季節リズムを実験室で再現するには, 光周期の操作 が基本である。自然の秋冬をシミュレートするため に, 短日環境に動物を曝す。多くの場合, 明 8 時間： 
暗 16 時間を用いたが, 温暖な $22{ }^{\circ} \mathrm{C}$ 程度でも精巣は委 縮をはじめ, 10 数週間で, 最も小さくなる。ところが, 明 16 時間：暗 8 時間のまま, 気温を下げても, 精巣 は期待したほど, 委縮しない。このことは, 進化の過 程で, 動物たちは, 変動の激しい気温に比べ, 一年を 通じ正確に変化する日長変化を, 季節マーカーとして, 選び取ったと考えられている。もちろん, 短日と寒冷 の二つの要因を加重すれば，より明瞭に季節リズムは 再現される。

これも光周期実験の常識なのだが, 短日環境（L8: D16）のもと，16 時間の暗開始より中頃で, 数秒でも 点灯すると, 精巣は委縮しなくなってしまう。忘れら れないのは, この夜間中断実験で, 全く精巣が委縮し ないのを見て, 学生の一人が感じ入ったように, “先 生，教科書通りですね”と言つたことである。このこ とは, 動物は, 暗期の絶対時間の長さに応答している わけでなく, 明あるいは暗開始を日の出, 日没と理解 していることを意味している。学生にとつて, この理 論はにわかには信じがたいものであったらしい。また, 精巣委縮の過程は，ノギスで測る方法もあるが，より 正確には, 摘出し, 重量を $1 \mathrm{mg}$ 単位で測定するのが 良い。短日寒冷環境では, $1 / 20$ 程度までに萎縮する。

季節性のリズムという長丁場の研究を学生・院生が 中心となって, 支えてくれた。彼らの協力がなければ, 全く, 研究室は成り立たず, 研究成果も得られなかつ た (Jap.Psychol.Res., 1992; Physiol.Behav., 1993; Jap. J.Anim.Psychol., 1998)。また，学生と一緒に仕事する と, 教えられることも多い。それに, 実験から離れて, デスクの前で良いアイディアは浮かばず, serendipity もない。何よりも，これまでの研究に対しては，学生 の諸君, また, 犠牲となった動物に対し, 感謝の気持 ちを持ち続けたい。

\section{4. むすび}

国立大学と私立大学, また研究所, さらには大学の 規模などにより, 研究に対する位置づけとスタッフの 意識は異なって, 当然である。加えて, 大学には教育 という大切な仕事があり, 今後ますます, その重要性 は増すことと思う。これを超えて, ずっと, 研究にこ だわり続けようとすると, どのようなことが問題とな るか。
まず, 研究対象に対して, マニアック, つまりオタ クであり続ける必要がある, と思う。それに, 実験系 の場合は, 指導者を含めた意味での研究環境も重要で ある。単に施設面だけでなく，人的サポート体制，資 金等である。もちろん, 自分自身の能力・資質は申す までもない。

現在では, 大きく改善されたが, 人文科学に属する 心理学は, 私たちの時代では, 博士課程を修了しても, 博士の学位は授与されないのが普通であった。社会科 学系も事情は, 変わらない。これでは, 進学する気も 起らないし, 国際的に通用する大学院として, 留学生 を集められない。この点で, 発足時より日本の人文・ 社会科学系の大学院は, その役割を果たしてこなかつ た, と言えよう。博士号取得は, 自立した研究者とし ての能力の保証で, ここでスタートラインに立つ。教 授の最大の仕事は, 学位を取得する学生の指導である, と理解している。

世界は, 科学, 経済を筆頭にグローバリゼーション が急速に進んでいる。知覚関係の国際心理学雑誌への 日本人論文は, ここ 30 年間で急速に増加している（佐 藤隆夫, 心理学ワールド, 2011)。この分野に限らず, 生理心理学の貢献も同じ傾向にあると思う。ますます, この傾向は加速されるであろう。若い皆さんは, 20 年, 30 年後を見据えて, この国際化への対応に向き合う 姿勢を養つてほしい。そのためには, 若い時代に留学 するのが, 非常に良い経験となる。自然科学の分野で は, ほとんどの研究者が, 何らかの留学体験を有して おり，このことがその学問の国際化を強く支えてい る。科学研究費補助金で, 外国出張が認められるよう になって, 久しいが, これは大変良い改革であったと 思う。2016 年に我が国で開催される国際心理学会は, このよい契機となると思う。皆さんの活躍を強く願つ ている。

\section{引用文献}

Ibuka, N. (1970). The influence of day-night cycles and the additive effects of methamphetamine and illumination on the spontaneous activity in rhesus monkeys (Macaca mulatta). Primates, 11, 101-111.

Ibuka, N. (1971). The relationship between visual exploratory behavior and spontaneous activity in rhesus monkeys 
(Macaca mulatta). Primates, 11, 201-214.

Ibuka, N. (1971). The differential effects of methamphetamine upon visual exploratory behavior and spontaneous motor activity in rhesus monkeys (Macaca mulatta). Japanese Psychological Research, 13, 26-33.

井深信男 (1972). バー押し場面におけるアカゲザル の視覚的探索行動と自発的活動に及ぼすメタンフェ タミンの効果 心理学研究, 43, 277-282.

Ibuka, N., \& Kawamura, H. (1975). Loss of circadian rhythm in sleep-wakefulness cycle in the rat by suprachiasmatic nucleus lesions. Brain Research, 96, 76-81.

Ibuka, N., Inouye, S. T., \& Kawamura, H. (1977). Analysis of sleep-wakefulness rhythms in male rats after suprachiasmatic nucleus lesions and ocular enucleation, Brain Research, 122, 33-47.

海老原史樹文（2010）。日本における時間生物学の発 展を振り返る 時間生物学, 16, 1-2.

Inouye, S. T., \& Kawamura, H. (1979). Persistence of circadian rhythmicity in a mammalian hypothalamic "island" containing the suprachiasmatic nucleus. Proceedings of the National Academy of Sciences, 76, $5962-5966$.

Sawaki, Y., Nihonmatsu, I., \& Kawamura, H. (1984). Transplantation of the neonatal suprachiasmatic nuclei into rats with complete bilateral suprachiasmatic lesions. Neuroscience Research, 1, 67-72.

Stephan, F. K., \& Zucker, I. (1972). Circadian rhythms in drinking behavior and locomotor activity of rats are eliminated by hypothalamic lesions, Proceedings of the National Academy of Sciences, 69, 1583-1586.

Moore, R. Y., \& Eichler, V. B. (1972). Loss of a circadian adrenal corticosterone rhythm following suprachiasmatic lesions in the rat. Brain Research, 42, 201-206.

Ibuka, N., Nihonmatsu, I., Sekiguchi, S. (1980). Sleep- wakefulness rhythms in mice after suprachiasmatic nucleus lesions. Waking Sleeping, 4, 167-173.

Ibuka, N. (1984). Ontogenesis of circadian sleepwakefulness rhythms and developmental changes of sleep in the altricial rat and in the precocial guinea pig. Behavioural Brain Research, 11, 185-196.

Ibuka, N. (1987). Circadian rhythms in sleep-wakefulness and wheel-running activity in a congenitally anophthalmic rat mutant. Physiology \& Behavior, 39, 321-326.

Ruby, N. F., Ibuka, N., Barnes, B. M., \& Zucker, I. (1989). Suprachiasmatic nuclei influence torpor and circadian temperature rhythms in hamsters. American Journal of Physiology, 257, R210-R215.

Ueda, S., \& Ibuka, N. (1995). An analysis of factors that induce hibernation in Syrian hamsters. Physiology \& Behavior, 58, 653-657.

Ibuka, N., \& Fukumura, K. (1997). Unpredictable deprivation of water increases the probability of torpor in the Syrian hamster. Physiology \& Behavior, 62, 551-556.

Ibuka, N., Ichikawa, S., \& Nishioka, H. (1993). Stress suppresses testicular and body weight in young Syrian hamsters under short photoperiod, Physiology \& Behavior, 53, 917-922.

Terada, A., \& Ibuka, N. (2000). Age affects hibernation in Syrian hamsters (mesocricetus auratus). Chronobiology International, 17, 623-630.

Ibuka, N. (1992). Photoperiodic regulation of body weight in Syrian hamsters Effects of prior photoperiodic history. Japanese Psychological Research, 34, 126-134.

Usui, T., \& Ibuka, N. (1998). Photoperiodic responsiveness in Mongolian gerbils. Japanese Journal of Animal Psychology, 48, 177-181.

佐藤隆夫 (2011). 心理学の国際化について 心理学 ワールド， 55, 1-1.

井深信男 (1990)。行動の時間生物学 朝倉書店 